石油技淮伤會鼓 第17卷 第 5 号 (昭和 27 年 9 月)

JOURNAL OF THE JAPANESE ASSOCIATION OF PETROLEUM TECHNOLOGISTS VOL. 17, NO. 5 (Sept., 1952)

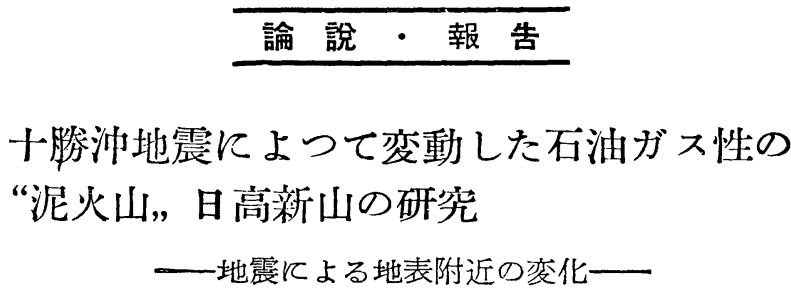

筒 浦明*

(昭和27年 6 月 27 日受理)

\title{
A Mud Volcano (Hidaka-Shinzan) Changed by an Earthquake at Tokachi Sea-coast
}

-One type of changes in the surface followed by the earthquake-

by Akira TSUTSUURA

Hidaka-shinzan, a mud volcano is said to have made some move when the earthquake at Tokachi Seacoast took place on March 4, 1952. But this was not a great action from the historical view-point of the mountain. We can find there an intermittent elevation. This is so-called "a living mountain," Although the mountain was formed after the formation of the terrace and before the eruption (B) of Mt. Usu, but the top of Hidaka-shinzan which made the movement last time was forened after the eruption (B) of Mt. Usu.

It is of a mountain with a plain on it and the river accross the elevation-axis (upheaval) is a zigzag and antecedent valley.

As above mentioned, the ground is unsettled and the soil is very sticky clay and unstable, then the land is not suitable for farming and is used only for pasture or raising grass for domestic animmals.

\section{1, 前 言}

1952年（昭和27年） 3 月 4 日,突然翏道以来の最大地震，十勝沖地震が起つた。そ の際戌生した日高国新冠村の日高新山について調弪したのでその概要を記したい。

な打当泥火山地域の東より 3 番目の泥火山は活動が最も甚しく, 大正 5 年頃より村 井・日石・日曹と第二次大戦前まで採油されたというが，gas の噴出が甚しく，事業 にしばしば困難が伴つた。

* 北海道札幌南高等祭校教官 
調查は 3 月29,30の両日筆者と研究補助者 1 名で行い, 微地形・微地筫・土瀷・植物 の生態・地震被害・地下水位等について研究した。

\section{2. 地 勢 一 般}

北海道の太平洋岸には，今村明恒博士の命名による外側地震装が島弧に平行に走つ ている。この地域の地震は明治29年, 昭和 8 年と大きい地震があつたが，今回（昭和 27年) のものが最大であり, 関東大地震に匹敵すると云われている。震源はェリモ岬 の東方 $70 \mathrm{~km}$, 地下 0 〜 $20 \mathrm{~km}$ の浅発地震 1)で, 海中のため津浪を伴つたが, 津浪は微 地形に支配され，ラッパ形の浅い海で波高が大になり，霧多布や浦河に被害が大きか つた。な誩該研究地である新冠静内附近は従来震源地が多く，当初の誤報もこれに基 くものであろら。

新冠附近の地形は，新冠川の左岸はいわゆる新冠牧場で海成段丘であり，右岸は古 い段丘が開析されその下方に河岸段丘が所々に残つている。この間を流れる新冠川の 広い沖積平野は，水田に利用されている。

この地帯の地質は新第三紀中新世中部の地層で，日高附近では門別層(空知地万で は岩見沢層・川端層 $\left.{ }^{2}\right)$ と呼ばれ含油層で，近接地節婦では採油した事るある。

震度は地質掅造に支配される事が多いが，日高山脈の背梁部では震度階級四なの

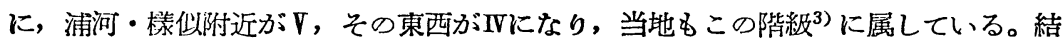
局蛇紋岩々の他の地帶に強く, 花崗岩に弱く, 第三紀の堆積岩類がその中間となる。 もつとも冲䅡地では一般に強く, 殊に泥若地に強く, 新築の学校でこの樣な土地に建 られたものが多いので倒壊したものも各地にある。日高新山の延長上の笔翌地带では 3 月 4 日の日中の有感地震は 9 回, 夜は 6 回であるが, 海岸の砂丘地带では日中 4 回, 夜 2 回を感じたに過ぎない。

\section{3. 今回活動した日高新山の成因}

この附近は泥岩・頁岩，及び集塊岩等よりなる地風であるが，地質時代に大きい䘯 曲を起して多くの趨や割れ目をもつている。十勝沖地震で初動方向が割れ目に直觕方 向に作用し, その割れ目が動、て, 割れ口から粘性の大きい泥土と gasを 3 ～ 4 日引 き続いて湧出したのである。過去に幾回も繰返されたことは, 正月のオソナェの如 く，幾つもの山を積み重ねた榡な断面をしているのでも知られる。文拖出物中には附 近の岩石と岩質を異にする角礫があつて, 破砕性を意味している。詰り含油層の背科 構造部に割れ目が出来て，gas を粘土と共に少々放出したと云らのが今回の状態であ る。処がたまたま地表が湅つていたので涷つた部分（厚さ約 $80 \mathrm{~cm}$ ) の地表がはがれ て, 震動と共にズリ落ちて来たもので, これ等の block(最大体積 $1.72 \mathrm{~m}^{3}$ )には粉々に

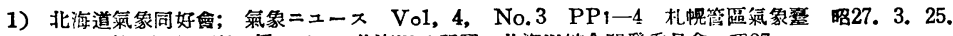

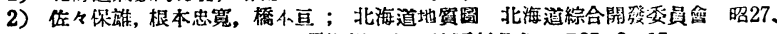

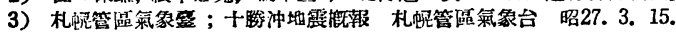


なつた部分や裏返しになつた土塊はなく，空中に放指したことを否定する。従つて，

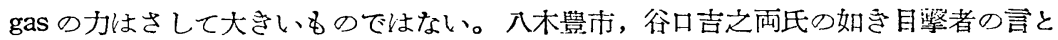
む完全に一致する。即ちこの山は泥火山 “mud volcano”に属するが，泥火山中の火 山性ならざるもので, 台湾の高雄瀼水溪にあるものと同一である。しかしその規模は

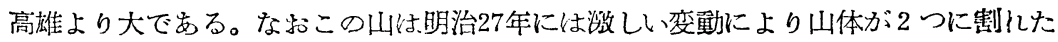
ことがある。

\section{4. 同樣な成因の 4 山}

2 万分の 1 下下方の地図をみると 4 つの山がある (第 1 四参照)。今, 新冠川の方か らA・B・C・D，と名附ける。このA山（今回活動した山）を土地の人は「タカイサラ」

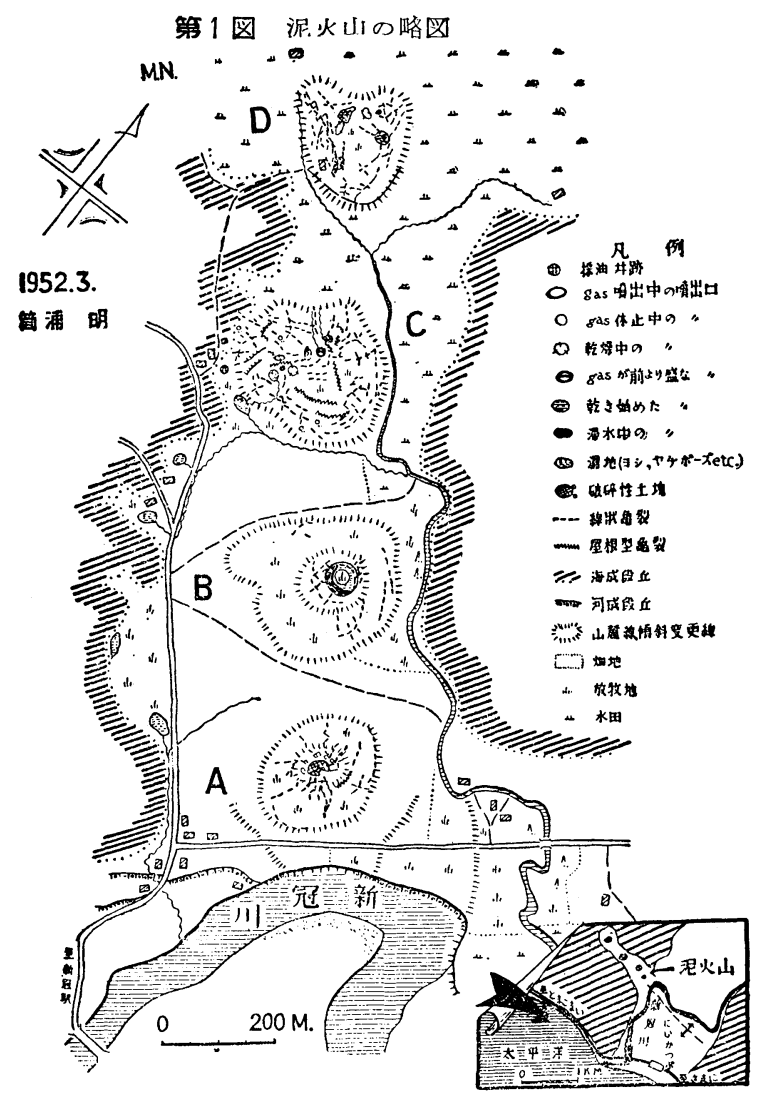

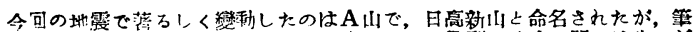

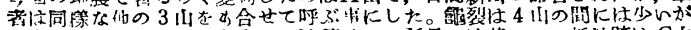

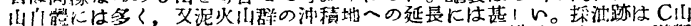

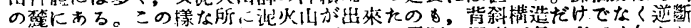

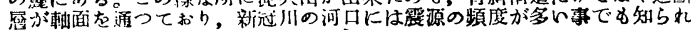
るように弱綄が存在するからであらら。
といらアイヌ語で呼ん でいる。「地震で出来 た山」の意げという。 今回の地震の象裂の中 で直線的なものはこ れ等の 4 つの山を結ん だ方向に伸び，冲賴地 では㨁緗的䇱裂が甚し く，大きいるのは7寸 にも及ぶロを開けてい る。

A 山は他の 3 山と形が 異り、オソナェを3つ 頪み重ねた樣な山に の形は間歇的隆起を意 味する。中村左衡門太 郎教授の昭和新山の実 験があるで，頂には 池や濕地はないが今回 の地霞でガサガサにな つている。この土塊を みるとヨシの根が地表 ろら $30 \sim 40 \mathrm{~cm}$ の部分 まで這大つていて，現 在は生えていないが， 嘗てはョシが生えてい た濕地があつたことが 
わかる。售裂は放射状のものと同心円状のものが明瞭である。比高は 4 つの山の中 2 番目に高く, 頂上部の土地利用は牧草地，下方は畑地になつていることは 4 つの山と も同樣である。

B山は 1 番高く特釜状で，殊に著しい特徽は頂部が平で円形の沼地があり，ヨシ・ ヤチボーズ（ヤチハンノキが10年前迄あつたが伐採した）等が生えている、集裂が池

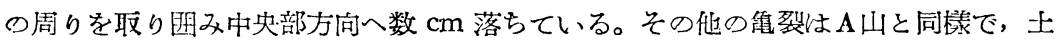
地利用も同じ放牧地である。

C山の規模は 1 番大きく, 特徴は7つ以上の池を有することと, 锤裂か激しい事で, 中には現在なお gas 梖出しているものもあり，休止しているものもある。及ヤチボ ーズの生えた濕地や広㷊樹の疎林がある。地形は台状で中央部がやや山み高さは第 3 位で，土地利用も他と同棂である。ただ，西侧の谷に採油の跡があり，3回にわたつ

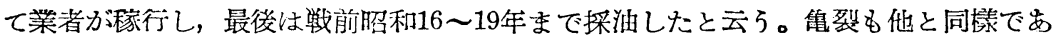
るが，屋根型にら出したものがあり，やや方向性に欠け椱雑である。

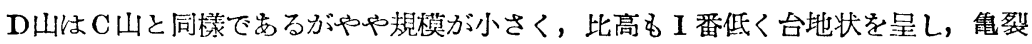
はやや不規則で gas の浚出はみられない。土地利用も同じである。

第2図 噴出孔から濕地の成生順序

5. 成長 の 歴 史

」鲁裂及的啨出孔成生

2 樯出任成生

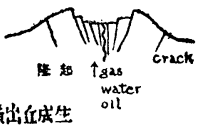

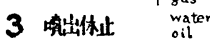

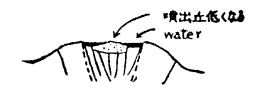 \\ or

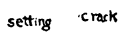

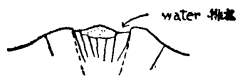

4 漯龙计堄

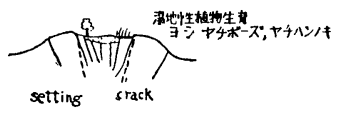

以上の観察より次の如くなる。地質は boringのdata によると軟い粘土で, $160 \mathrm{~m}$ 迄にoil 4 ケ所, gas 5 ヶ所 の幊油がみられた。先づ地震その他で背科情造の部分 に䉼嚿か兒裂が出来て，石油ガスや地下水，泥土*(含 油層及びその上部の) が溢此をする。（第 2 区参照） これ等の泥土が縊出した後には，多少の空隌をみたす settingがあり，又地震があれしばsettingが甚しくなつて 回地がより窪んでくる。又湓水は出口をみつけて流出 するので㻏蝕もしばしば行われる。gas を溢出中の䈯 所ではgasと共に地下水を流㤷，mudやclayは貲出口附 近に堆䅪して口の部分を cone型に高くし， gasの溢仙 が休止すれてば泥土も地下水も止り粘性の大きい土は平 になり, 以後の雨水や融雪水で洗われ几四形が目けミ゙て くる。gas の溢出中に出来たアスファルト状のものが 無くなる頃には，濕地性のヨシやヤチボーズが生えて くる。中にはこの頃になつても中央が小高く円い背を なしている所もあるがここの場合には眀かな湓出口を

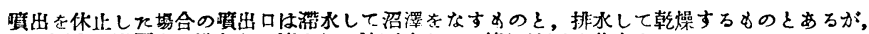
何れも雨水や融雪水に洗われて流され, 沈下むあって終には濕地化する。

*C门I妇土中より有孔虫の化石を檢出

Haplophragmoides cf. compressum Leroy,

Dentalima sp. (sp. indeterminable) 
持つていない場合に多い。そして可地の水が流出口の传蝕, その他で完全に排水され

第 3 図土垻断面

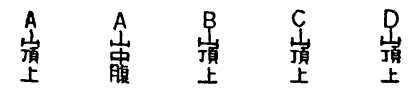

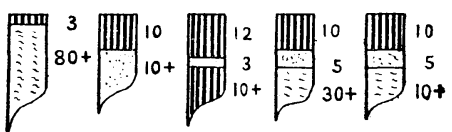

血监售植土

（單位Cm）

\section{有珠B降交}

軟后六色呫土

A 凹の原上は, 他の 3 山と異り, 有珠系火山 灰夲缺く點に注意。詰り山原部の成生はB系降 灰後と云う毒になる。

た前に何れも出来ているが，A山の現 在の櫴出した山の部分のみ火山灰がな く，それ以後の櫴出と云える。又段 目の海成段丘よりも比高は低く下段の 河岸段丘よりも高いが，水畨嘫をどの 山も持なない。従つて段丘形成後の成 生といらことになり，地質的には最近 の成生である。

(第 3 目，第 4 図参照)

\section{6. 地震と被害}

先ず冲箖地では地制にが甚しく4つ の山の直線方向のものが激しいが，4 つの山の間には少く，むしろ同心円
れば，濕地でなくなつてヨシも枯れて終う。

さて土壤断面を作つてみると第 3 図の如くな り，有珠B(1853年降灰) $)^{4)}$ 采の火山灰の降灰し
第4 図噴出孔の活動歴史

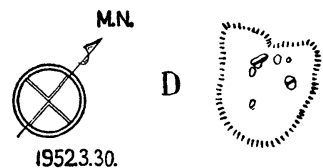

散浦 明

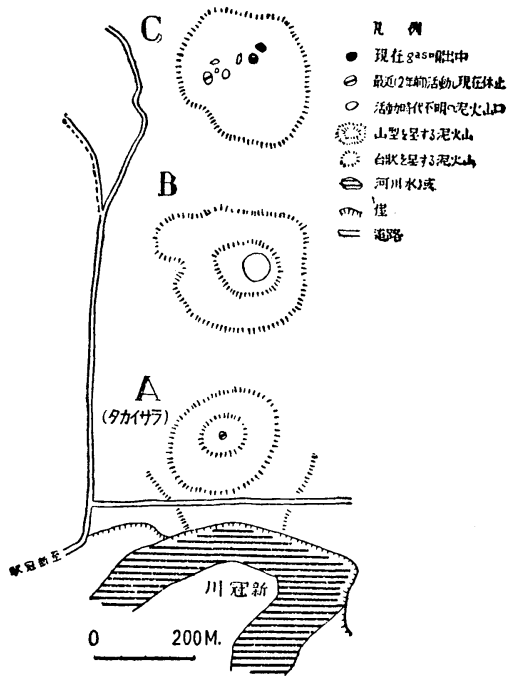

山形から見ると3ty peに分かれるが，現在乾燥している

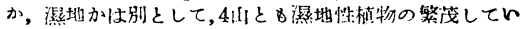

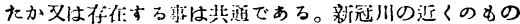

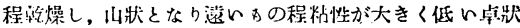
となつていろのは、荘冠川人地下水が徐々にこ代れて㛺

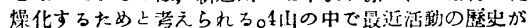
絕えていろのはB叫で,最む覞模の大きい沼池が存在する。

状，放射状の委裂が甚だしい。こ狆等の土地は放牧地のため䭾の放牧が困難になつた 程度である。隆起量も 0.6 1m位の程度らしく，凍土の厚さげけでも最大 $80 \mathrm{~cm}$ あ つたのでこの程度のものらしい。然し若し下部から隆起しているとすれはば，植物生態 学的な方法を用いると，4 m位になるが確定ではない。

地下水は釧路・十勝・日高一滞に買状を呈したが5)，当地でも被害を受けている。

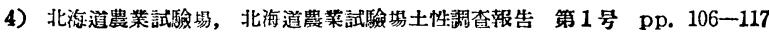

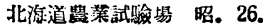


海岸でも水が出なくなり，A山附近の 8 幹の観測の結果は 5 〜 尺位も地下水面が低 くなつた。これは直接の隆起なのか，割れ目に地下水が流入する結果なのか速断は出 来ない。

家屋の被害はこの山の延長上の 2 軒が最も甚しく，何れも内部の建具迄もやられて いる。この線上の飛渡啓次郎・山岡栄太郎両家とも振動方向はNNE-SSW方向 ${ }^{\boldsymbol{\sigma}}$ で, 山岡氏の新しい虔はこの方向に（SSW方向へ） $20 \mathrm{~cm}$ も移動している。然しその他で は集合㖶突の倒壤，ガラスの破壊，その他があるのみで冲積地でも案外被害は少く， 微地質埥造や運動方向に支配されているのか解る。

\section{7. 地形に現れた隆起運動}

日高の太平洋岸一带に海岸段丘・河岸段丘が存在して間歇的隆起を示す事は，渡辺 光・小笠原義勝両氏等先学の研究があり, 運動の方向も傾動的であると云われている。 一方最近の, 即ち平野成生以後の運動も中野尊正氏によ的ば，石狩・勇払原野では， 小さい沈降と隆起が繰返されている。

新冠川の河口 (第 1 図参照) みみるとZ字形に河が曲り左岸の方がより高くなり， ここが先行谷的に隻蝕されている。かつこの部分は 4 つの山の延長でまつて，道路の cutting でも常に土が落ちて植生がなく，又この川への延長は馬の背の如くなり，川 岸のcuttingでは他と異る岩相をなしている(地質傋造は背斜と逆断層をなしている)。 冲䆅地への 4 つの山の延長は大きい黾裂となつている。文濕地や他の四地をたどつて も河道が直流した跡は少く，最近はZ形が著るしくなつている。

新冠川の河口附近は 2 列の海岸砂丘よりなつていて内陸側の方に集落が占居し, 海 側のものは末利用で，砂互間の凹地は放牧地になつている。この部分の地質をみると 内陸側の砂丘砂は台状の部分の上方に乗上り，前列砂丘の間が段になつているらしく 隆起運䌾を思わせる。

即ち，以上の事からこの㧼な山の成生と共に，隆起運動が間歇的に起つているよ5 である。このZ字形は附近の他の河川ではみられないから極く局部的な隆起現象であ ろら。

\section{8. 結言}

昭和27年 3 月 4 日の十勝沖地震に活動したと云われる「日高新山」は「泥火山で」 あつて，山の歴史からみると大きい活動ではないが地震の時に活動する石油ガス性の 山で,この附近に間㰽的な隆起運動が存在する「生きた山」である。この山は段丘形

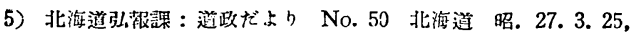

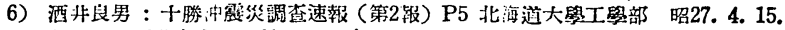
各地の主要動方向は物所により骇々であう。

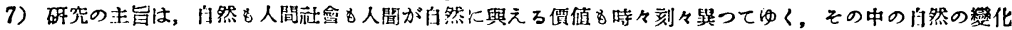

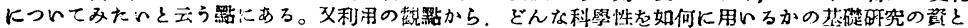

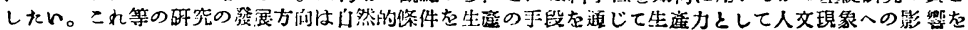
見るという力向をとりれい。 
成後有珠 B櫴火前に成生したが，今度活勤した山の頂は有珠 B喷火後のものでする 8)。以上の如く土地も変勒が多くかつ土壤は粘性の大きい不安定粘土で, 耕地として は不適当なため，牧草地又は放牧地に利用されているに過ぎない。

この研究費は北海道の地震対策費より支出された。な就研究の便宜を与えられた北 海道消防課長佐々木雄助氏に感謝する次第である。文地資資料の提供・鑑定豆項いた 帝石北海道釷栄所開発䛞長竹田秀蔵氏に対し御礼申上げる。

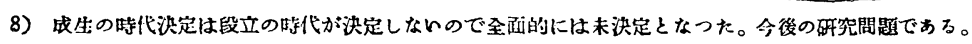

